\title{
Pengaruh Ketimpangan Gender Terhadap Pertumbuhan Ekonomi di Provinsi Jambi
}

\author{
Utari Endah Pertiwi $^{1 *}$, Heriberta $^{2}$, Hardiani $^{3}$ \\ 1,2,3 Prodi Ekonomi Pembangunan, Fakultas Ekonomi dan Bisnis, Universitas Jambi
}

\begin{tabular}{|l|l|l|l|}
\hline Diterima: 10-11-2021 & Direvisi: 08-12-2021 & Disetujui: 20-12-2021 & Dipublikasi: 31-12-2021 \\
\hline
\end{tabular}

\begin{abstract}
This study aims to analyze the effect of gender inequality on economic growth in Jambi Province. The data used is the 2015-2018 time series in districts/cities in Jambi Province. The estimation model uses panel data regression. The analysis results found that gender inequality has a negative effect on economic growth. In other words, increasing gender inequality will affect the decline in economic growth.
\end{abstract}

Keywords: gender inequality index, welfare, economic growth

\begin{abstract}
Abstrak
Penelitian ini bertujuan untuk menganalisis pengaruh ketimpangan gender terhadap pertumbuhan ekonomi di Provinsi Jambi. Data yang digunakan adalah runtut waktu 2015-2018 pada kabupaten/kota di Provinsi Jambi. Model estimasi menggunakan regresi data panel. Hasil analisis menemukan ketimpangan gender berpengaruh negatif terhadap pertumbuhan ekonomi. Dengan kata lain,meningkatnya ketimpangan gender akan berpengaruh terhadap penurunan pertumbuhan ekonomi.
\end{abstract}

Kata kunci: Indeks Ketimpangan Gender, kesejahteraan, pertumbuhan ekonomi

\section{Pendahuluan}

Pertumbuhan ekonomi merupakan salah satu indikator keberhasilan pembangunan di suatu daerah. Tingginya pertumbuhan ekonomi diharapkan akan dapat meningkatkan taraf hidup masyarakat, serta pencapaian kemakmuran bangsa dan daerah. Efektivitas pertumbuhan ekonomi akan lebih terjamin jika diikuti dengan meningkatnya kualitas sumber daya manusia serta berkurangnya kesenjangan antara laki-laki dan perempuan. Kesenjangan tersebut baik dalam hal peranannya ataupun perolehan hak-hak atas meningkatnya perekonomian. Perempuan yang sering kali menjadi penerima pasif dari manfaat pertumbuhan ekonomi diharapkan dapat meningkatkan perannya dalam pertumbuhan ekonomi. Melalui hal tersebut proses pembangunan tidak akan menyisakan masalah kesenjangan/ketimpangan gender.

Pada dasarnya tidak terdapat perbedaan kesempatan perempuan dan laki-laki untuk berpartisipasi dan berkontribusi di bidang ekonomi. Meskipun demikian, faktanya tidak mudah bagi perempuan untuk terjun kedalam kegiatan ekonomi. Budaya dan pola pikir yang telah mengakar di kehidupan masyarakat terkait kedudukan perempuan membuat kaum perempuan harus menghadapi berbagai macam kendala untuk berkarya. Memiliki kontrol berarti memiliki kewenangan untuk mengambil keputusan atas penggunaan dan hasil sumber daya sehingga memperoleh manfaat yang sama dari berbagai cara untuk mengatur

\footnotetext{
* Penulis korespondensi

Email: utariendah1315@gmail.com
} 
perekonomian. Hal ini disebabkan kesetaraan gender akan memberikan akses bagi para perempuan untuk berkontribusi dalam pergerakan ekonomi suatu bangsa. Akibatnya, pergerakan ekonomi akan semakin efektif dan perempuan juga lebih dihargai perannya.

Salah satu tujuan dari delapan tujuan Millenium Development Goals (MDGs) adalah mendorong kesetaraan gender dan pemberdayaan perempuan. Hal tersebut sesuai dengan tujuan pembangunan manusia Indonesia yaitu mencapai kesetaraan gender untuk meningkatkan kualitas sumber daya manusia tanpa membedakan laki-laki dan perempuan. Kesetaraan gender tidak hanya menjadi masalah wanita tapi menjadi persoalan pembangunan. Pemberdayaan perempuan terutama dalam masalah ekonomi diperlukan untuk pembangunan ekonomi, pertumbuhan ekonomi dan pengurangan kemiskinan. Meskipun demikian, diskriminasi pada berbagai aspek kehidupan masih banyak terjadi. Diskriminasi tersebut terjadi baik dalam hal persamaan hak, akses terhadap sumber pendidikan, kesehatan dan ketenagakerjaan (Harahap, 2014).

Pengertian gender tidak merujuk pada jenis kelamin tertentu. Secara konsep, gender mengacu pada hubungan antara laki-laki dan perempuan, anak laki-laki dan anak perempuan dan bagaimana hubungan sosial ini dikontruksikan. Oleh karenanya, peran gender bersifat dinamis dan berubah antara waktu (Kementerian Pemberdayaan Perempuan dan Perlindungan Anak, 2011).

Dalam rangka peningkatan kesetaraan dan keadilan gender, pemerintah mengeluarkan Intruksi Presiden Nomor 9 Tahun 2000 Tentang Pengarusutamaan Gender dalam Pembangunan Nasional. Strategi pengarusutamaan gender mengikutsertakan dalam perencanaan hingga evaluasi kebijakan dan program pembangunan nasional. Namun kenyataan menunjukan bahwa diskriminasi gender masih banyak terjadi dalam seluruh aspek kehidupan. Diskriminasi perempuan terjadi dalam persamaan hak, mengakses sumber pendidikan dan kesehatan, ketenagakerjaan dan partisipasi politik.

Ketidaksetaraan gender menyebabkan pilihan- pilihan yang tersedia bagi perempuan menjadi terbatas. Hal ini kemudian membatasi kemampuan perempuan untuk berpartisipasi atau menikmati hasil dari pembangunan.. Ketidaksetaraan gender pada tahap selanjutnya akan berdampak pada penurunan produktivitas, efesiensi, dan kemajuan ekonomi. Dengan menahan akumulasi sumber daya manusia di rumah dan di pasar tenaga kerja, serta dengan sistematis mengecualikan perempuan atau laki-laki dari akses ke sumber daya, jasa politik, atau aktifitas produktif, maka diskriminasi gender mengurangi kapasitas suatu perekonomian untuk tumbuh serta mengurangi kapasitas untuk meningkatkan strandar kehidupan (World Bank, 2005).

Partisipasi perempuan secara umum dikelompokan dalam dua peran yaitu, peran tradisi dan transisi (Handayani, dkk., 2008). Peran tradisi adalah peran perempuan sebagai istri dan ibu rumah tangga. Peran transisi adalah peran perempuan sebagai tenaga kerja, dan anggota masyarakat pembangunan.

Salah satu indeks yang terkait dengan gender adalah Indeks Pembangunan Gender (IPG). IPG mengukur pencapaian dalam dimensi yang sama dengan Indeks Pembangunan Manusia (IPM), tetapi mengungkap ketidaksetaraan dalam pencapaian antara perempuan dan laki-laki. (UNDP, 2004). Sebagaimana halnya IPM, IPG juga dipengaruhi oleh beberapa komponen yaitu angka harapan hidup (AHH), angka melek huruf (AMH), rata-rata lama sekolah (MYS) dan pengeluaran perkapita. Meskipun demikian, secara teori terdapat perbedaan mendasar IPM dan IPG dalam konteks hubungannya dengan pertumbuhan ekonomi. IPM diharapkan akan berpengaruh positif (Permana dkk, 2020), sebaliknya IPG diharapkan berpengaruh negatif terhadap pertumbuhan ekonomi. 
Untuk mengetahui ketimpangan gender maka kesenjangan nilai IPG dan IPM dapat digunakan. Jika nilai IPG sama dengan nilai IPM maka tidak terjadi kesenjangan gender. Jika IPG lebih rendah dibandingkan IPM dapat disimpulkan terjadi kesenjangan gender.

Selama periode Tahun 2015 - 2018, indeks ketimpangan gender di Provinsi Jambi cenderung mengalami penurunan. Hal ini tentunya kondisi yang menggembirakan dan diharapkan menjadi salah satu faktor pemicu pembangunan. Oleh karenanya, penelitian ini bertujuan untuk menganalisis pengaruh ketimpangan gender terhadap pertumbuhan ekonomi di Provinsi Jambi.

\section{Metode}

Data yang digunakan dalam penelitian ini adalah data kabupaten/kota di Provinsi Jambi selama periode Tahun 2015 - 2018. Data bersumber dari BPS Provinsi Jambi. Data dianalisis menggunakan model regresi data panel dengan persamaan sebagai berikut:

$$
\mathrm{PE}_{\mathrm{it}}=\boldsymbol{\beta 0}-\boldsymbol{\beta 1} \mathrm{IKG}_{\mathrm{it}}+\mathrm{e}_{\mathrm{it}}
$$

Keterangan :

$$
\begin{aligned}
\mathrm{PE} & =\text { Pertumbuhan Ekonomi } \\
\mathrm{IKG} & =\text { Indeks Ketimpangan Gender } \\
& =\text { Konstanta } \\
& =\text { Koefisien Elastisitas } \\
\mathrm{e} & =\text { Standar Error }
\end{aligned}
$$

\section{Hasil dan Pembahasan}

\section{Pertumbuhan Ekonomi di Provinsi Jambi Periode 2015-2018}

Pertumbuhan ekonomi merupakan salah satu tolok ukur untuk mengukur prestasi perekonomian dari satu periode ke periode berikutnya. Bagi daerah, ini merupakan suatu indikator yang penting untuk mengetahui keberhasilan pembangunan dan berguna untuk menentukan arah kebijakan pembangunan di masa yang akan datang.

Pertumbuhan ekonomi kabupaten/kota di Provinsi Jambi Tahun 2015 - 2018 diberikan pada Tabel 1.

Tabel 1. Pertumbuhan Ekonomi Kab/Kota di Provinsi Jambi Tahun 2015-2018

\begin{tabular}{lccccc}
\hline \multicolumn{1}{c}{ Wilayah } & $\mathbf{5}$ & Pertumbuhan Ekonomi (\%) & Rata-Rata \\
& $\mathbf{2 0 1 5}$ & $\mathbf{2 0 1 6}$ & $\mathbf{2 0 1 7}$ & $\mathbf{2 0 1 8}$ & \\
\hline Kerinci & 6,45 & 6,7 & 6,03 & 5,36 & 6,14 \\
Merangin & 5,48 & 6,21 & 5,55 & 4,89 & 5,53 \\
Sarolangun & 3,09 & 4,26 & 4,69 & 5,12 & 4,29 \\
Batanghari & 4,36 & 4,55 & 4,82 & 5,09 & 4,71 \\
Muaro Jambi & 5,24 & 5,43 & 5,06 & 4,69 & 5,11 \\
Tanjung Jabung Timur & 1,87 & 2,7 & 3,13 & 3,56 & 2,82 \\
Tanjung Jabung Barat & 3,98 & 3,14 & 4,25 & 5,36 & 4,18 \\
Tebo & 5,28 & 5,38 & 5,6 & 5,82 & 5,52 \\
Bungo & 5,13 & 5,2 & 5,67 & 6,14 & 5,54 \\
Kota Jambi & 5,56 & 6,81 & 4,68 & 5,55 & 5,65 \\
Kota Sungai Penuh & 7,06 & 6,51 & 6,24 & 5,97 & 6,45 \\
Provinsi Jambi & 4,86 & 5,17 & 5,07 & 5,23 & 5,08 \\
\hline
\end{tabular}

Sumber : BPS Provinsi Jambi, 2021

Rata-rata pertumbuhan ekonomi di Provinsi Jambi selama periode Tahun 2015 - 2018 sebesar 5,08 persen pertahun. Ketimpangan pertumbuhan ekonomi ini terlihat antar kabupaten/kota di Provinsi Jambi. Disparitas pembangunan antar kabupaten/kota ini tidak 
hanya terlihat dari sisi pertumbuhan ekonomi. Sebagaimana temuan Safitri dkk (2021), ketimpangan pembangunan antar kabupaten/kota di Provinsi Jambi juga terlihat baik dari sisi ekonomi maupun non-ekonomi.

Pertumbuhan ekonomi tertinggi tercatat di Kota Sungai Penuh yaitu 6,45 persen pertahun. Tingginya pertumbuhan ekonomi ini dikarenakan sektor pertanian merupakan sektor yang mendominasi dan berperan dalam roda perekonomian di Kota Sungai Penuh. Pertumbuhan ekonomi terendah tercatat pada Kabupaten Tanjung Jabung Timur, hanya sebesar 2,82 persen pertahun. Rendahnya pertumbuhan ekonomi di daerah ini disebabkan keterbatasan potensi sumber daya alam.

\section{Indeks Ketimpangan Gender di Provinsi Jambi Periode 2015-2018}

Gender adalah seperangkat peran, perilaku, kegiatan dan atribut yang dianggap layak bagi laki-laki dan perempuan (World Health Organization, 2021). Gender mengacu pada peran yang dikontribusikan masyarakat dan perilaku-perilaku yang dipelajari serta harapanharapan yang dikaitkan pada perempuan dan pada laki-laki. Gender merupakan kategori sosial yang paling menentukan kesepakatan hidup dan peran serta seseorang dalam masyarakat dan ekonomi.

Eitzen menjelaskan terdapat 2 penyebab munculnya ketimpangan gender: (a) ketimpangan gender sebagai sebuah outcome tentang bagaimana perempuan dan laki-laki diikat terhadap kepada ekonomi masyarakat. (b) Pembedaan ruang lingkup domestik dengan publik dari aktivitas menyebabkan perempuan dibatasi geraknya. Peran reproduksi perempuan dan tanggung jawabnya pada pekerja domestikmembuatnya terbatas untuk mengakses sumber daya yang bernilai tinggi

Tabel 2. Indeks Ketimpangan Gender Kab/Kota di Provinsi Jambi Tahun 2015-2018

\begin{tabular}{|c|c|c|c|c|c|}
\hline \multirow[t]{2}{*}{ Wilayah } & \multicolumn{4}{|c|}{ Indeks Ketimpangan Gender } & \multirow[t]{2}{*}{ Rata-Rata } \\
\hline & 2015 & 2016 & 2017 & 2018 & \\
\hline Kerinci & 0,542 & 0,538 & 0,534 & 0,464 & 0,520 \\
\hline Merangin & 0,855 & 0,851 & 0,838 & 0,896 & 0,860 \\
\hline Sarolangun & 0,612 & 0,608 & 0,569 & 0,565 & 0,589 \\
\hline Batanghari & 0,571 & 0,567 & 0,522 & 0,524 & 0,546 \\
\hline Muaro Jambi & 0,545 & 0,541 & 0,527 & 0,528 & 0,535 \\
\hline Tanjung Jabung Timur & 0,557 & 0,553 & 0,53 & 0,505 & 0,536 \\
\hline Tanjung Jabung Barat & 0,575 & 0,571 & 0,552 & 0,535 & 0,558 \\
\hline Tebo & 0,552 & 0,548 & 0,581 & 0,542 & 0,556 \\
\hline Bungo & 0,569 & 0,565 & 0,555 & 0,557 & 0,562 \\
\hline Kota Jambi & 0,299 & 0,295 & 0,182 & 0,243 & 0,255 \\
\hline Kota Sungai Penuh & 0,594 & 0,59 & 0,743 & 0,81 & 0,684 \\
\hline Provinsi Jambi & 0,552 & 0,548 & 0,528 & 0,511 & 0,535 \\
\hline
\end{tabular}

Sumber : BPS Provinsi Jambi, 2021

Tabel 2 menunjukkan bahwa indeks ketimpangan gender kabupaten/kota di Provinsi Jambi selama periode tahun 2015 sampai tahun 2018 cenderung mengalami penurunan. Ratarata indeks ketimpangan gender di Provinsi Jambi sebesar 0,535. Indeks ketimpangan gender tertinggi tercatat pada Kabupaten Merangin dengan rata-rata indeks ketimpangan gender sebesar 0,860 setiap tahunnya, tingginya indeks ketimpangan gender di Kabupaten Merangin dikarenakan didaerah ini partisipasi angkatan kerja laki-laki jauh lebih besar dibanding partisipasi kerja perempuan, misalnya pada tahun 2018 tingkat partispasi angkatan kerja lakilaki yaitu sebesar 87,09 persen, sementara tingkat partispasi angkatan kerja perempuan yaitu hanya sebesar 51,76 persen. Sedangkan indeks ketimpangan gender terendah tercatat pada daerah Kota Jambi yaitu hanya sebesar 0,255. Rendahnya indeks ketimpangan gender di Kota 
Jambi dikarenakan rata-rata lama sekolah laki-laki dan perempuan nilainya hampir sama besar begitu juga dengan tingkat partisipasi angkatan kerjanya.

\section{Pengaruh Indeks Ketimpangan Gender Terhadap Pertumbuhan Ekonomi}

Dalam menganalisis data panel yaitu dengan menggunakan tiga metode yang dapat digunakan untuk estimasi data panel, yaitu metode Common-Constans (PLS), metode Fixed Effect (FEM), dan metode Random Effect (REM). Pendekatan PLS ini menggunakan metode OLS biasa.

Untuk menentukan model yang paling tepat digunakan dalam mengestimasi data panel, maka akan dilakukan pengujian pemilihan model dengan menggunakan Chow Test, Hausman Test dan Uji Lagrange Multiplier. Metode penentuan model dengan menggunakan Chow Test adalah menentukan metode yang mana yang terbaik antara metode PLS atau FEM. Seandainya metode PLS yang terbaik, maka tidak perlu dilakukan uji Hausman namun dilanjutkan dengan Uji Lagrange Multiplier untuk menentukan metode mana yang terbaik antara PLS dan REM, akan tetapi jika FEM yang terbaik maka akan dilanjutkan pengujian dengan ujian Hausman untuk menentukan metode yang terbaik antara metode FEM atau REM. Berikut ini akan ditampilkan hasil pengujian tersebut:

Chow Test (Uji Chow) Dilakukan untuk membandingkan/memilih model mana yang terbaik antara PLS dan FEM.

Tabel 3. Uji Chow untuk memilih antara model PLS dengan FEM

\begin{tabular}{lcrc}
\hline \hline Effects Test & Statistic & d.f. & Prob. \\
\hline \hline Cross-section F & 26.983995 & $(10,32)$ & 0.0000 \\
Cross-section Chi-square & 98.743085 & 10 & 0.0000 \\
\hline \hline
\end{tabular}

Tabel 3 menunjukkan bahwa baik $F$ test maupun Chi-Square signifikan (Probabilitalebih kecil dibandingkan $\alpha=0,05$ ). Hipotesis Ho ditolak dan H1 diterima. Dengan demikian, dapat disimpulkan bahwa model FEM lebih baik dibandingkan model PLS.

Pengujian berikutnya adalah membandingkan metode FEM atau REM melalui uji hasuman. Hausman Test (Uji Hausman), sebagaimana diberikan pada Tabel 4.

Tabel 4. Uji Hausman untuk memilih antara model FEM dengan REM

\begin{tabular}{lrrr}
\hline \hline Test Summary & Chi-Sq. Statistic & Chi-Sq. d.f. & Prob. \\
\hline \hline Cross-section random & 2.379178 & 1 & 0.1230 \\
\hline \hline
\end{tabular}

Sumber: Data Diolah, Eviews 9 (2021)

Tabel 4 menunjukkan bahwa nilai Prob. Breusch-Pagan (BP) sebesar 0,0000. Nilai Prob BP $(0,0000)<0,1$ maka H0 ditolak, dengan kata lain model yang cocok adalah Random Effect Model.

\section{Estimasi Model REM}

Berdasarkan hasil dari ketiga uji ini, maka model terbaik adalah model REM. Hasil estimasi regresi data panel pengaruh indeks ketimpangan gender terhadap pertumbuhan ekonomi diberikan pada Tabel 5. 
Tabel 5. Hasil Estimasi Random Effects Model (REM)

\begin{tabular}{|c|c|c|c|c|}
\hline Variable & Coefficient & Std. Error & t-Statistic & Prob. \\
\hline 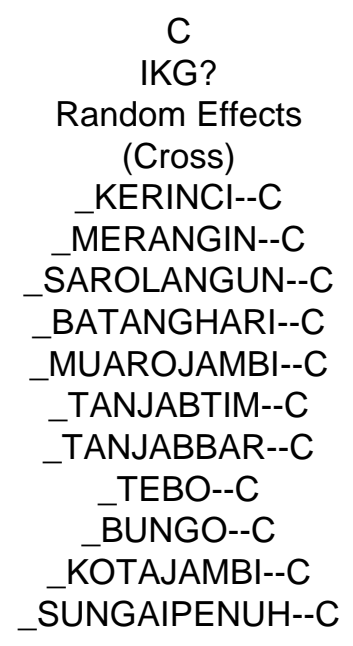 & $\begin{array}{r}-0.510675 \\
-0.518712 \\
-0.467806 \\
-0.265068 \\
0.008965 \\
0.123312 \\
0.218651 \\
0.308540 \\
0.560233 \\
0.777394 \\
-0.234833\end{array}$ & $\begin{array}{l}0.372589 \\
0.616679\end{array}$ & $\begin{array}{r}23.10062 \\
-10.14596\end{array}$ & $\begin{array}{l}0.0000 \\
0.0000\end{array}$ \\
\hline \multicolumn{5}{|c|}{ Effects Specification } \\
\hline $\begin{array}{l}\text { Cross-section random } \\
\text { Idiosyncratic random }\end{array}$ & & & $\begin{array}{l}0.439675 \\
0.165176\end{array}$ & $\begin{array}{l}0.8763 \\
0.1237\end{array}$ \\
\hline \multicolumn{5}{|c|}{ Weighted Statistics } \\
\hline $\begin{array}{l}\text { R-squared } \\
\text { Adjusted R-squared } \\
\text { S.E. of regression } \\
\text { F-statistic } \\
\text { Prob(F-statistic) }\end{array}$ & $\begin{array}{l}0.703531 \\
0.696473 \\
0.167866 \\
99.66760 \\
0.000000\end{array}$ & \multicolumn{2}{|c|}{$\begin{array}{l}\text { Mean dependent var } \\
\text { S.D. dependent var } \\
\text { Sum squared resid } \\
\text { Durbin-Watson stat }\end{array}$} & $\begin{array}{l}0.938409 \\
0.304694 \\
1.183521 \\
0.979252\end{array}$ \\
\hline \multicolumn{5}{|c|}{ Unweighted Statistics } \\
\hline $\begin{array}{l}\text { R-squared } \\
\text { Sum squared resid }\end{array}$ & $\begin{array}{l}0.831907 \\
9.261199\end{array}$ & $\begin{array}{l}\text { Mean depen } \\
\text { Durbin-Wats }\end{array}$ & $\begin{array}{l}\text { lent var } \\
\text { on stat }\end{array}$ & $\begin{array}{l}5.083182 \\
0.125142\end{array}$ \\
\hline
\end{tabular}

Sumber: Data Diolah, Eviews 9 (2021)

Untuk menguji signifikasi pengaruh indeks ketimpangan gender terhadap pertumbuhan ekonomi pada kabupaten/kota di Provinsi Jambi secara parsial maka digunakan uji t statistik. Uji t Statistik berguna untuk melihat besarnya pengaruh masih-masing variabel Independen terhadap variabel dependen secara parsial. Tingkat kepercayaan 95 persen dengan uji dua arah dan dapat diterangkan hasil uji t statistik sebagai berikut:

Jika dilihat dari Prob indeks ketimpangan gender sebesar 0,0000 karena Prob $<0,05$, maka H0 ditolak dan Ha diterima. Ini menunjukkan bahwa indeks ketimpangan gender berpengaruh signifikan terhadap pertumbuhan ekonomi pada kabupaten/kota di Provinsi Jambi.

Berdasarkan hasil regresi pada model FEM disebutkan nilai koefisien indeks ketimpangan gender sebesar -6,256. Hal ini diartikan jika indeks ketimpangan gender meningkat satu maka pertumbuhan ekonomi kabupaten/kota di Provinsi Jambi menurun sebesar -6,256 persen. Hasil penelitian ini sejalan dengan Aktaria dan Handoko (2012), Klasen dan Lamanna (2009), Baliamoune-Lutz dan McGillivray (2007). Hasil penelitian ini 
berbeda dengan temuan Nazmi dan Jamal (2018) yang menunjukkan tidak adanya pengaruh ketimpangan gender terhadap pertumbuhan ekonomi.

\section{Kesimpulan dan Saran}

\section{Kesimpulan}

Hasil penelitian menunjukkan bahwa ketimpangan gender berpengaruh negatif terhadap pertumbuhan ekonomi. Hal ini berarti ketika terjadi peningkatan ketimpangan gender, akan berdampak pada penurunan pertumbuhan ekonomi.

\section{Saran}

Pemerintah Provinsi Jambi perlu meningkatkan anggaran untuk melaksanakan program-program kesetaraan gender dan meningkatkan pengawasan program-program anggaran tersebut sehingga bisa dimanfaatkan sesuai dengan tujuan kesetaraan gender..

\section{Daftar Pustaka}

Aktaria, E. dan Handoko, B. (2012). Ketimpangan Gender dalam Pertumbuhan Ekonomi. Jurnal Ekonomi Pembangunan. 13(2), 194- 206.

Badan Pusat Statistik. (2018). Badan Pusat Statistik Provinsi Jambi dalam angka (20092018). BPS Kota Jambi.

Baliamoune-Lutz, M. and Gillivray, M. (2007). Gender inequality and growth: Evidence from Sub-Sahara Africa and Arab countries. African Development Review. 21(2): 224-242

Gorman, B. K., \& Read, J. G. (3 Mei 2007). Why men die younger than women. Medscape. https://www.medscape.com/viewarticle/555221

Gujarati, D. N., \& Porter, D. C. (2012). Dasar-dasar Ekonometrika. Salemba Empat.

Handayani, T., Sugiarti, \& Dharma, S. (2008). Konsep dan Teknik Penelitian Gender. UMM Press.

Harahap, R. F. A. (2014). Analisis pengaruh ketimpangan terhadap pertumbuhan ekonomi di Provinsi Jawa Tengah [Skripsi]. Ilmu Ekonomi dan Studi Pembangunan Universitas Diponegoro.

Kementerian Pemberdayaan Perempuan dan Perlindungan Anak. (2011). Konsep dan Definisi. http://:menegpp.go.id.

Klasen, S. and Lamanna, F. (2009). The Impact of Gender Inequality in Education and Employment on Economic Growth: New Evidence for a Panel of Countries. Feminist Economist.15(3): 91-132

Nazmi, L. \& Jamal, A. (2018). Pengaruh Ketimpangan Gender Terhadap Pertumbuhan Ekonomi Di Indonesia. Jurnal Ilmiah Mahasiswa, 3(4), 740-750

Permana, B., Yulmardi, Y., \& Junaidi, J. (2020). Pengaruh komponen indeks pembangunan manusia (IPM) terhadap pertumbuhan ekonomi di Kota Jambi Periode 20042018. E-Jurnal Ekonomi Sumberdaya Dan Lingkungan, 9(2), 110-122. https://doi.org/10.22437/jels.v9i2.11954

Purba, U. (2016). Analisis pengaruh ketimpangan gender terhadap pertumbuhan ekonomi di Provinsi Lampung [Skripsi]. Universitas Lampung.

Safitri, E., Junaidi, J., \& Erfit, E. (2021). Analisis disparitas pembangunan antar Kabupaten/Kotadi Provinsi Jambi(segi ekonomi dan non ekonomi). Jurnal Paradigma Ekonomika, 16(1), 141-150. https://doi.org/10.22437/jpe.v16i1.10156

United Nation Development Program (UNDP). (2004). Indeks Pembangunan Manusia. www.undp.org 
Winarno, W. W. (2011). Analisis Ekonometrika dan Statistika dengan Eviews. UPP STIM YKPN.

World Bank. (2005). Pembangunan Berperspektif Gender. Dian Rakyat.

World Health Organization. (22 Juni 2021). Gender: Definitions. https://www.euro.who.int/en/health-topics/health-determinants/gender/genderdefinitions akses terbuka yang didistribusikan di bawah syarat dan ketentuan Lisensi Atribusi Creative Commons (CC BY-SA) (http://creativecommons.org/licenses/by/4.0/) 